\title{
Impact of Urbanization on the Hydrological Cycle of Migina Catchment, Rwanda
}

\author{
Olivier Clement Gatwaza ${ }^{*}$, Xin Cao ${ }^{1}$, Mukete Beckline ${ }^{2}$ \\ ${ }^{1}$ School of Landscape Architecture, Beijing Forestry University, Beijing, China \\ ${ }^{2}$ Department of Forest Management, Beijing Forestry University, Beijing, China \\ Email: "colgat4@yahoo.com,478659173@qq.com, munasawa@gmail.com
}

Received 16 June 2016; accepted 15 July 2016; published 19 July 2016

Copyright (C) 2016 by authors and OALib.

This work is licensed under the Creative Commons Attribution International License (CC BY).

http://creativecommons.org/licenses/by/4.0/

(c) (i) Open Access

\begin{abstract}
In this study, we carry out an assessment of the impact of urbanization on Butare, southern Rwanda and evaluate its effect on the hydrological process at the Migina catchment. We used data from the meteorological stations of the Migina catchment, land-use maps of the region (obtained in 1974 and 2010) and GIS technology in order to analyse hydrological fluctuations in Migina catchment and the expansion of Butare town. We observed that, between the two hydrological years (1974 and 2010) water runoff increased by over 3.5\% with increasing flood risks. Furthermore, evapotranspiration and groundwater level have decreased by about $3 \%$ and $0.5 \%$ leading to water scarcity. Research on urban planning is necessary in order to improve on water resources management and reduce the effects of urbanization on water resources such as in the Migina catchment.
\end{abstract}

\section{Keywords}

Water Resources, Urban Planning, Urbanization, Hydrological Cycle, Land Cover, Migina Catchment Rwanda

Subject Areas: Agricultural Science, Biodiversity, Conservation Biology, Ecology, Environmental Sciences, Hydrology, Natural Geography

\section{Introduction}

Rain water, either returns to the atmosphere through evapotranspiration or infiltrates the soil, runs off on the surface and likely ends up into a river, ocean or lake (Figure 1) [1]-[3]. The relative proportions depend on the nature of the surface, duration of rainfall and intensity [1] [3] [4].

"Corresponding author. 


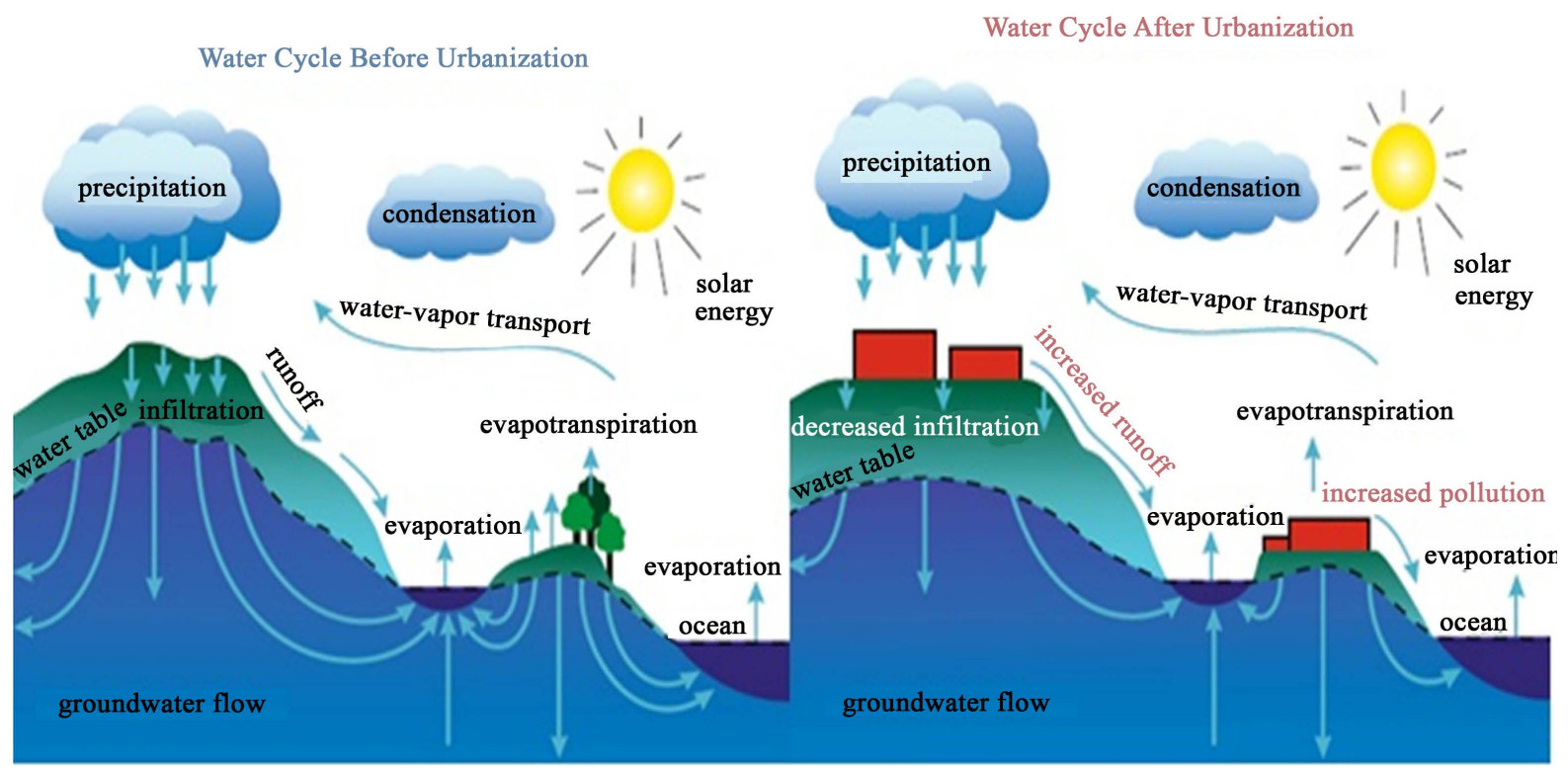

Figure 1. Water cycle diagram showing different processes involved before and after urbanization. Sourced from UNCE, 2015.

Development of an urban area involves covering the ground with artificial surfaces, and it significantly increases the amount of surface runoff in relation to infiltration and evapotranspiration (Figure 2). This therefore increases the total volume of water reaching the river when or after it rains. As a result, this will reduce water that would be stored within a catchment and contribute to water scarcity [5]. Furthermore, the construction of storm sewers and culvert of natural streams and channels which takes place during urbanization results in water being transmitted into the drainage network more rapidly; this increases outflow velocity [6] [7]. Since a larger runoff is discharged within a shorter interval, peak rate of water inevitably increases, giving rise to the danger of sudden flooding of rivers. These subsequent floods damage human and natural resources as well as properties [8].

When people develop within a watershed, the hydrologic cycle is affected. The increase in impervious or hard surfaces, including rooftops and pavement (roads, driveways, and parking lots) decreases the amount of water that soaks into the ground or infiltrates [2] [9]. This increases the amount of surface runoff (Figure 3). If infiltration is significantly decreased, groundwater levels may decline, affecting stream flows especially during the dry season. Meanwhile, lowered groundwater levels can result in subsequent well failures [1] [10]. While the effects of urbanization on the water cycle can be major, if wise choices are made during the development process, the impacts can be minimized and future water supply can be protected [10] [11].

Although Rwanda is among the least urbanized countries with an urban population of 28.8\% in 2015 [12], it had a rapid population growth of about 2.7\% in 2010-2015 (UN, 2016) and a relatively high urbanization rate of $6.43 \%$ in 2015 [12] [13]. On the other hand in Rwanda, observations from existing data showed that over the last 30 years, some parts of Rwanda have experienced unusual irregularities in climate patterns including variability in rainfall frequencies and intensity, persistence of extreme weather conditions such as heavy rainfall in the northern regions and drought in the eastern and southern regions [14].

The meso-scale Migina catchment $\left(257.57 \mathrm{~km}^{2}\right.$ ) located in southern Rwanda experiences serious human activities in its northern zone. This is as a result of the rapid urbanization of Butare town as it progressively destroys the natural land cover surrounding the catchment area. The topography and land cover of drainage basins affect phenomena like erosion sediments that are transported from storm runoffs towards rivers. These produce changes in water balances of the concerned drainage basin [15]. Also, as new development projects are continuously being implemented within the area, their growing impact affects the hydrologic cycle in general [3] [10] [16].

The importance of the hydrological cycle has been in existence for billions of years and continuously renews and refreshes finite water supplies [10]. Therefore, lack of public awareness on implication of their daily activi- 


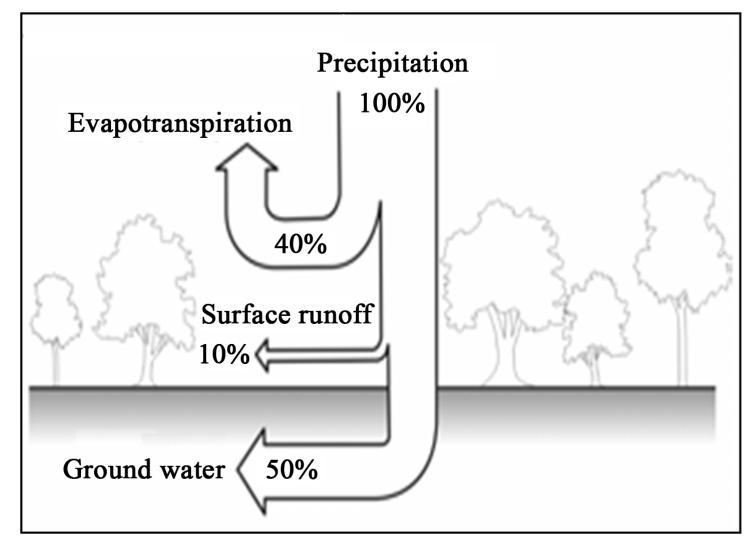

(a)

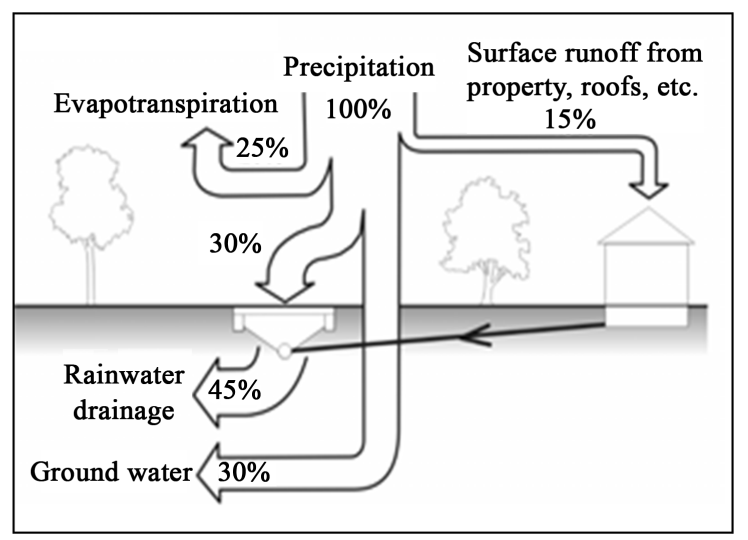

(b)

Figure 2. Effect of urbanization on hydrological cycle. Sourced from Carlos, 2007. (a) Pre-urbanization; (b) Urbanization.

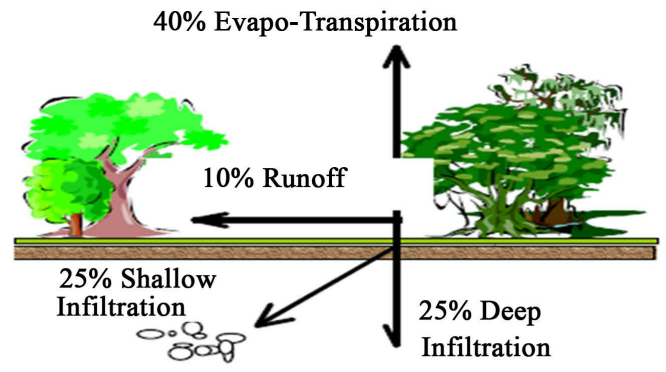

Natural Ground Cover

$35 \%$ Evapo-Transpiration

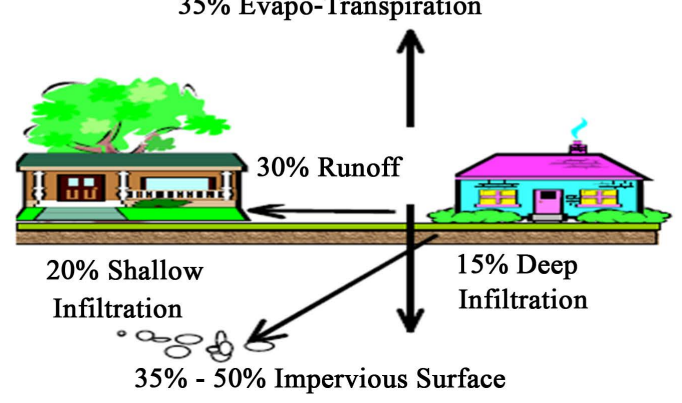

$38 \%$ Evapo-Transpiration
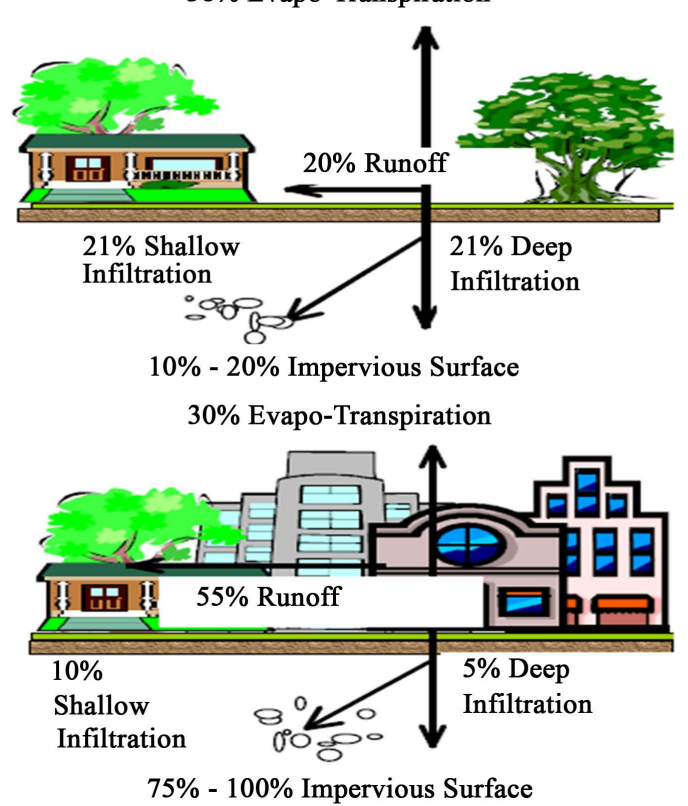

Figure 3. Influence of urbanization on different components of the water cycle. Sourced from CWP, 2015.

ties on water resources has contributed to its inefficient use and scarcity. This paper looks at urbanization of Butare town and studies its effects on the long term availability of water resources within the catchment. The study strives to espouse scientific evidence that would aid the local population, urban planners and decision makers, such as to promote cleaner and safer urban expansion while ensuring continuous water availability within the Migina catchment.

\section{Methodology and Data Analysis}

\subsection{Study Area}

Migina catchment is located between $2^{\circ} 32^{\prime}$ and $2^{\circ} 48^{\prime}$ South, $29^{\circ} 42^{\prime}$ and $29^{\circ} 48^{\prime}$ East, in the Southern province of Rwanda. It is drained by perennial streams with the main flow following a north to south direction. The main stream is located in the eastern part of the catchment with most of the valleys draining from north-west to south-east towards the main stream. The Migina catchment drains into the Akanyaru River, which forms the border between Rwanda and Burundi. Downstream, the Akanyaru River joins the Nyabarongo River to form the 
Kagera River, which is the largest tributary of Lake Victoria and a precursor of the Nile River, Figure 4.

The Migina catchment area is mountainous with elevation ranging from $1434 \mathrm{~m}$ in the south to $2251 \mathrm{~m}$ around the Huye Mountains in the North West. Land use is dominated by pasture and arable farming such as rice, sorghum, maize, and sweet potato [17]. Butare town, with over 100,000 inhabitants is located in Huye district, stretching along the main axes of Akanyaru, Nyabarongo and Kagera Rivers.

The meteorological data recorded from different meteorological stations in the catchment (Butare airport, $\mathrm{Bu}-$ tare mission, Kansi and Rubona) shows that the mean annual temperature is around $24^{\circ} \mathrm{C}$ and shows a progressive increase in the area's temperature, Figure 5 [18].

\subsection{Determination of Two Annual Water Balances}

The water balance is an account of the inputs and outputs of water, and it often applies to a watershed or a surface water reservoir. Any difference between the inflow $(I)$ and the outflow $(O)$ over a certain time period represents the water that has entered or left stored $(S)$ within the catchment [19].

$$
I-O= \pm S
$$

According to [15], the water balance may also be written as;

$$
A(P-E)-Q=\Delta S
$$
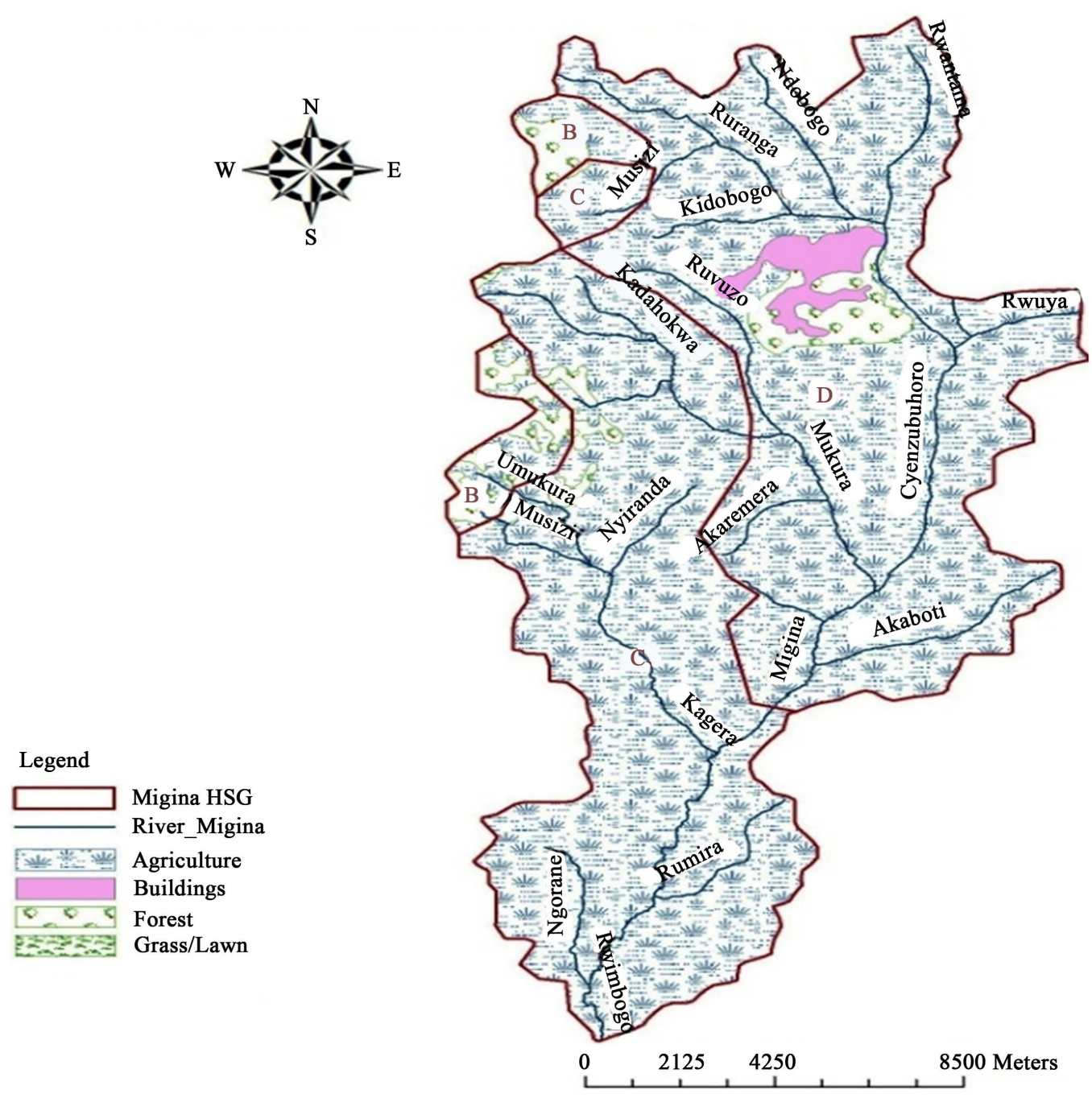

Figure 4. Land cover of Migina catchment. 


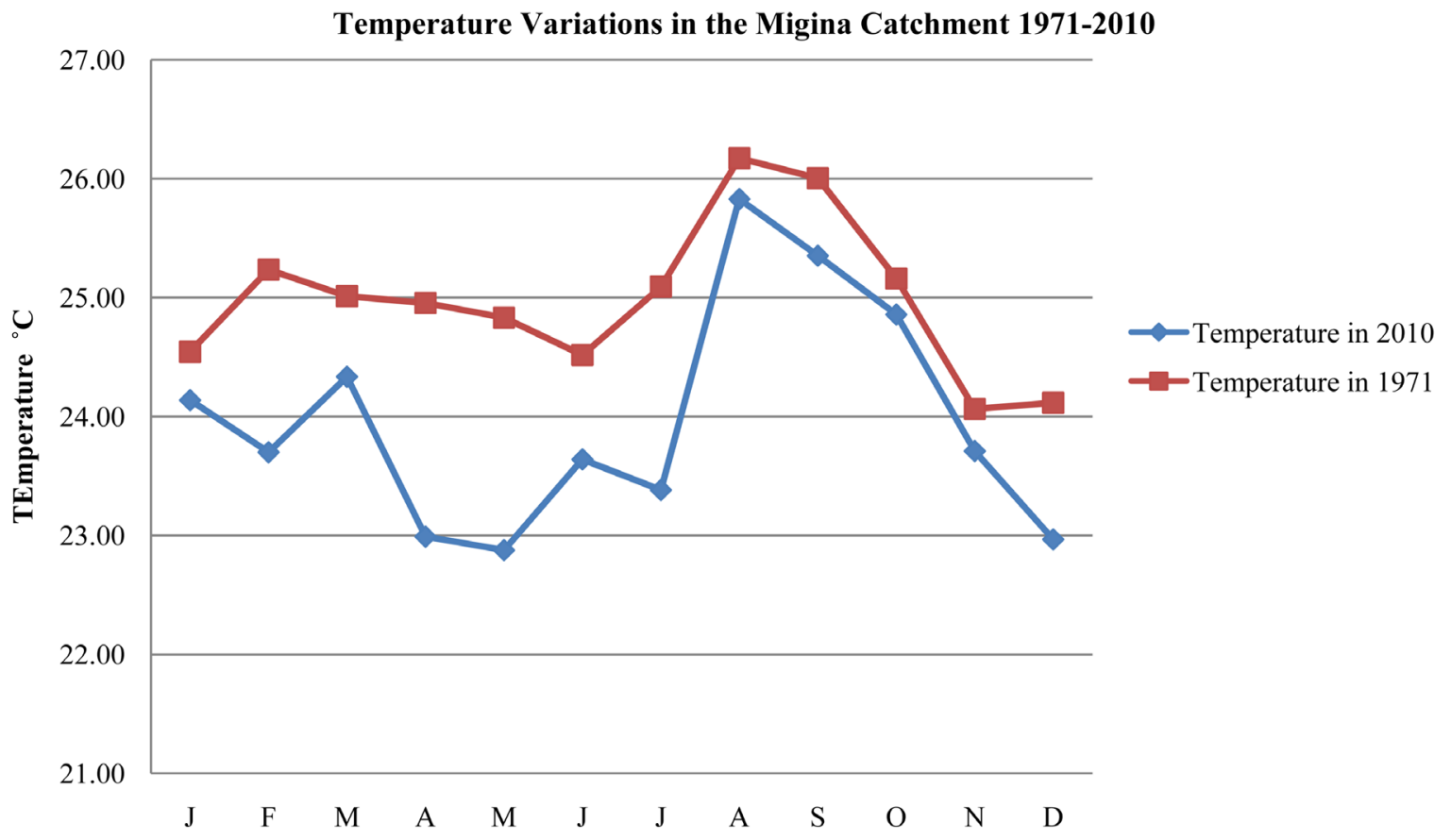

Figure 5. Mean annual temperature variation within the study area between 1971 and 2010.

The present study considers Inflow as Precipitation $(P)$, as Evapotranspiration $(E)+$ Outlet discharge $(Q)$, while Stock $(S)$ is the quantity of water stored in the catchment. The components of water balance were thus estimated by:

The measured evaporation $\left(E_{p a n}\right)$ has to be compensated with a pan factor $\left(f_{\text {pan }}\right)$ to obtain the real open water evaporation [20].

$$
E T_{\text {ref }}=f_{p a n} E_{p a n}
$$

We used the most popular method for the calculation of the potential evapotranspiration (PET), which computes the crop evapotranspiration according to [16]. Where $k_{c}$ is the crop factor and $E T_{\text {ref }}$ is the reference evapotranspiration.

$$
E T_{\text {pot }}=k_{c} E T_{\text {ref }}
$$

The actual evaporation $(A E T)$ is then calculated by:

$$
A E T=P E T \times K_{a d j}
$$

The Rational Formula for estimating peak runoff rate, introduced in the USA in 1889 has become widely used as a tool for drainage design, particularly for sizing water conveyance structures [21].

$$
Q=K I \sum_{i=1}^{n} C_{i} A_{i}
$$

where, $Q$ is the peak runoff rate $\left(\mathrm{m}^{3} / \mathrm{s}\right), C$, the runoff coefficient (unit less, ranging from 0 to 1 ) while $I$ is the rainfall intensity (mm/hr), and $A$ is the watershed area (ha). The conversion factor $K$ is an estimated value 0.00278 (unit less).

\subsection{Determination of Inflow}

Rainfall data was collected from 12 meteorological stations located within the catchment area between June 2009 and May 2011 and Thiessen polygons were used to estimate the mean annual rainfall, Table 1.

Similarly, the quantity of water that entered the catchment between 1973 and 1974 was obtained by collecting data from four rain gauges installed at Save, Butare airport, Nyakibanda and Kansi. Thiessen polygons were then used to calculate the mean (average) annual rainfall, Table 2. 
Table 1. Annual rainfall for 2009/2011 using Thiessen polygon method.

\begin{tabular}{|c|c|c|c|c|c|c|c|c|c|c|c|c|c|}
\hline YEAR & Month & $\begin{array}{l}\text { Rango } \\
\text { P (mm) }\end{array}$ & $\begin{array}{c}\text { Mubumbano } \\
\text { P (mm) }\end{array}$ & $\begin{array}{l}\text { Murama } \\
\text { P (mm) }\end{array}$ & $\begin{array}{l}\text { Vumbi } \\
\mathbf{P}(\mathbf{m m})\end{array}$ & $\begin{array}{l}\text { Mpare } \\
\text { P (mm) }\end{array}$ & $\begin{array}{l}\text { Sovu } \\
\text { P (mm) }\end{array}$ & $\begin{array}{l}\text { Save B } \\
\text { P (mm) }\end{array}$ & $\begin{array}{l}\text { Muyira } \\
\text { P (mm) }\end{array}$ & $\begin{array}{l}\text { Kibilizi } \\
\text { P (mm) }\end{array}$ & $\begin{array}{l}\text { Gisunzu } \\
\text { P (mm) }\end{array}$ & $\begin{array}{c}\text { Rwasave } \\
\text { P (mm) }\end{array}$ & $\begin{array}{l}\text { Kansi A } \\
\mathbf{P}(\mathbf{m m})\end{array}$ \\
\hline \multirow{7}{*}{2009} & June & 6.73 & 7.57 & 4.46 & 5.72 & 10.94 & 12.79 & 4.04 & 18.68 & 7.41 & 21.60 & 4.00 & 20.20 \\
\hline & July & 1.01 & 0.00 & 0.00 & 0.00 & 0.17 & 2.52 & 0.67 & 0.84 & 5.55 & 0.17 & 1.60 & 0.00 \\
\hline & August & 22.55 & 48.22 & 50.16 & 26.93 & 38.71 & 4.38 & 2.78 & 40.06 & 25.00 & 28.61 & 3.50 & 55.63 \\
\hline & September & 50.24 & 59.58 & 56.89 & 44.27 & 47.63 & 55.71 & 28.95 & 42.25 & 43.09 & 48.05 & 37.70 & 89.38 \\
\hline & October & 134.99 & 94.51 & 91.99 & 66.49 & 78.02 & 151.82 & 121.44 & 55.38 & 64.47 & 132.82 & 129.30 & 113.00 \\
\hline & November & 202.57 & 116.81 & 122.70 & 191.38 & 250.96 & 211.41 & 201.81 & 112.60 & 110.16 & 141.72 & 168.50 & 113.50 \\
\hline & December & 123.55 & 120.01 & 131.96 & 119.34 & 132.38 & 134.65 & 136.42 & 128.76 & 63.62 & 127.74 & 51.70 & 111.10 \\
\hline \multirow{12}{*}{2010} & January & 199.29 & 209.81 & 182.46 & 335.29 & 226.39 & 151.99 & 190.28 & 213.60 & 148.96 & 219.68 & 134.40 & 147.13 \\
\hline & February & 208.38 & 260.64 & 238.93 & 237.66 & 183.44 & 180.52 & 183.63 & 280.25 & 167.98 & 253.48 & 288.70 & 288.20 \\
\hline & March & 320.90 & 161.59 & 159.99 & 153.00 & 148.04 & 158.05 & 84.92 & 229.42 & 134.07 & 161.43 & 205.50 & 194.06 \\
\hline & April & 390.92 & 168.23 & 144.92 & 226.39 & 245.67 & 158.81 & 123.55 & 196.17 & 142.57 & 181.87 & 112.60 & 138.88 \\
\hline & May & 194.26 & 259.21 & 177.45 & 154.01 & 234.67 & 163.32 & 111.66 & 214.89 & 176.31 & 141.10 & 172.22 & 166.38 \\
\hline & June & 32.08 & 33.41 & 53.81 & 46.79 & 27.50 & 23.38 & 11.92 & 11.00 & 7.70 & 27.50 & 17.88 & 37.58 \\
\hline & July & 0.00 & 0.00 & 0.00 & 0.00 & 0.00 & 0.00 & 0.00 & 0.00 & 0.00 & 0.00 & 0.00 & 0.00 \\
\hline & August & 0.00 & 0.00 & 0.00 & 0.00 & 0.00 & 0.00 & 0.00 & 0.00 & 0.00 & 0.00 & 0.00 & 0.00 \\
\hline & September & . 256.67 & 77.09 & 103.03 & 51.00 & 74.25 & 126.50 & 103.13 & 66.92 & 59.13 & 79.48 & 106.33 & 97.81 \\
\hline & October & 231.00 & 51.84 & 114.31 & 47.30 & 90.75 & 107.71 & 53.17 & 62.33 & 45.83 & 45.93 & 92.13 & 52.34 \\
\hline & November & 286.92 & 147.45 & 157.12 & 108.40 & 141.17 & 39.88 & 115.96 & 172.33 & 99.88 & 120.54 & 138.42 & 89.83 \\
\hline & December & 151.25 & 87.36 & 108.63 & 109.49 & 154.00 & 77.46 & 185.17 & 70.13 & 103.22 & 119.63 & 107.25 & 93.59 \\
\hline \multirow{5}{*}{2011} & January & 196.17 & 100.82 & 101.57 & 97.96 & 118.25 & 98.08 & 252.08 & 87.08 & 108.17 & 73.61 & 154.92 & 293.33 \\
\hline & February & 239.25 & 144.67 & 89.83 & 74.40 & 132.92 & 192.04 & 150.88 & 166.83 & 132.55 & 125.03 & 197.54 & 179.76 \\
\hline & March & 220.00 & 130.53 & 178.20 & 126.91 & 132.46 & 126.96 & 123.75 & 326.79 & 126.50 & 186.08 & 145.29 & 148.59 \\
\hline & April & 420.75 & 147.19 & 120.54 & 127.25 & 155.83 & 109.08 & 141.17 & 546.33 & 333.30 & 178.75 & 142.54 & 136.68 \\
\hline & May & 285.08 & 112.60 & 122.28 & 102.00 & 141.17 & 86.63 & 129.25 & 125.58 & 197.82 & 124.30 & 118.25 & 87.82 \\
\hline \multicolumn{2}{|c|}{$\begin{array}{l}\text { An. Rain. } \\
\text { 1st Year (mm) }\end{array}$} & 1855.39 & 1506.19 & 1361.90 & 1560.47 & 1597.01 & 1385.99 & 1190.16 & 1532.90 & 1089.18 & 1458.28 & 1309.72 & 1437.44 \\
\hline \multicolumn{2}{|c|}{$\begin{array}{c}\text { An. Rain. } \\
\text { 2nd Year (mm) }\end{array}$} & 2319.17 & 1032.97 & 1149.32 & 891.49 & 1168.29 & 987.71 & 1266.47 & 1635.33 & 1214.08 & 1080.84 & 1220.54 & 1217.33 \\
\hline \multicolumn{2}{|c|}{$\begin{array}{c}\text { Annual Rainfall } \\
(\mathbf{m m})\end{array}$} & 2087.28 & 1269.58 & 1255.61 & 1225.98 & 1382.65 & 1186.85 & 1228.31 & 1584.12 & 1151.63 & 1269.56 & 1265.13 & 1327.39 \\
\hline \multicolumn{2}{|c|}{$\begin{array}{c}\text { Thiessen } \\
\text { Polygon }\left(\mathrm{Km}^{2}\right)\end{array}$} & 18.18 & 33.81 & 34.35 & 23.99 & 6.36 & 34.72 & 11.82 & 11.45 & 11.27 & 28.72 & 17.45 & 25.45 \\
\hline
\end{tabular}

\subsection{Determination of Outflow}

Data for pan evaporation $\left(E_{p a n}\right)$ were obtained from two self-made replications of the US Weather Bureau "Class A" evaporation pans installed at the Rwasave fishpond and Gisunzu meteorological station. The reference potential evapotranspiration was established for data collected from June 2009 to May 2011. In order to obtain the real open water evaporation, the estimated $E_{\text {pan }}$ was to be compensated for by a pan factor $\left(f_{\text {pan }}\right)$, where the pan factor depends on the type of pan used, pan environment and climate. For the "Class A" evaporation pan, 
Table 2. Annual rainfall for 1973/1974 using Thiessen polygon method (mm).

\begin{tabular}{|c|c|c|c|c|c|}
\hline Year & Month & Butare $\mathbf{P}(\mathbf{m m})$ & Kansi P(mm) & Nyakibanda $\mathbf{P}(\mathrm{mm})$ & Save $P(\mathbf{m m})$ \\
\hline \multirow{12}{*}{1973} & January & 182.40 & 120.40 & 190.00 & 123.50 \\
\hline & February & 110.50 & 176.30 & 67.80 & 100.10 \\
\hline & March & 84.70 & 42.70 & 61.40 & 90.50 \\
\hline & April & 141.00 & 223.20 & 189.10 & 177.60 \\
\hline & May & 228.60 & 211.00 & 252.30 & 334.80 \\
\hline & June & 54.50 & 20.70 & 0.00 & 19.50 \\
\hline & July & 0.00 & 0.00 & 0.00 & 0.00 \\
\hline & August & 3.60 & 17.70 & 0.00 & 16.20 \\
\hline & September & 216.30 & 182.60 & 166.50 & 133.80 \\
\hline & October & 117.50 & 107.60 & 146.50 & 66.90 \\
\hline & November & 154.00 & 104.80 & 109.80 & 163.90 \\
\hline & December & 72.20 & 69.50 & 104.80 & 36.50 \\
\hline \multirow{12}{*}{1974} & January & 77.50 & 62.60 & 71.60 & 46.90 \\
\hline & February & 58.90 & 49.90 & 100.80 & 85.00 \\
\hline & March & 253.80 & 152.40 & 167.30 & 164.90 \\
\hline & April & 172.00 & 172.50 & 183.40 & 211.40 \\
\hline & May & 117.20 & 138.90 & 119.20 & 142.70 \\
\hline & June & 71.90 & 16.80 & 30.10 & 51.50 \\
\hline & July & 21.20 & 17.60 & 29.70 & 49.40 \\
\hline & August & 12.90 & 0.00 & 0.00 & 4.20 \\
\hline & September & 90.30 & 69.20 & 114.80 & 117.10 \\
\hline & October & 55.00 & 47.80 & 45.00 & 17.70 \\
\hline & November & 178.40 & 162.30 & 104.60 & 179.90 \\
\hline & December & 86.40 & 125.90 & 91.80 & 77.00 \\
\hline \multicolumn{2}{|c|}{ Annual Rainfall 1973 (mm) } & 1365.30 & 1276.50 & 1288.20 & 1263.30 \\
\hline \multicolumn{2}{|c|}{ Annual Rainfall 1974 (mm) } & 1195.50 & 1015.90 & 1058.30 & 1147.70 \\
\hline \multicolumn{2}{|c|}{ Avg. Annual Rainfall (mm) } & 1280.40 & 1146.20 & 1173.25 & 1205.50 \\
\hline \multicolumn{2}{|c|}{ Thiessen Polygon $\left(\mathrm{Km}^{2}\right)$} & 60.30 & 105.02 & 58.77 & 33.47 \\
\hline
\end{tabular}

$f_{\text {pan }}$ varies between 0.35 and 0.85 with an average value of 0.70 [20]. Based on a relative high humidity ( $\left.>70 \%\right)$, moderate wind speed and green crops on a windward side distance in the order of $10 \mathrm{~m}$ [20], an empirically derived pan factor of 0.55 was used, Table 3.

The final, actual or adjusted crop factors $\left(K_{a d j}\right)$ was calculated as shown in Table 4.

The dominant crops and their corresponding characteristics were described in [7] and the adjusted evaporation coefficient $\left(K_{a d j}\right)$ is therefore equal to 0.74 .

The Actual Evapotranspiration (Equation (2.5)) becomes:

$$
A E T=854.88 \mathrm{~mm} \times 0.74=632.61 \mathrm{~mm}
$$


Table 3. Reference evapotranspiration for 2009-2011 (mm).

\begin{tabular}{|c|c|c|c|c|c|}
\hline \multirow{2}{*}{ Year } & \multirow{2}{*}{ Month } & Rwasave E (mm) & Gisunzu E (mm) & Avg. E (mm) & ET $(\mathrm{mm})$ \\
\hline & & Column (1) & Column (2) & $(3)=(1)^{*}(2) / 2$ & $0.55^{*}(3)$ \\
\hline \multirow{7}{*}{2009} & June & 140.00 & 125.60 & 132.80 & 66.40 \\
\hline & July & 218.60 & 145.17 & 181.88 & 90.94 \\
\hline & August & 145.50 & 113.61 & 129.56 & 64.78 \\
\hline & September & 140.70 & 154.05 & 147.38 & 73.69 \\
\hline & October & 151.30 & 141.80 & 146.55 & 73.28 \\
\hline & November & 149.50 & 138.68 & 144.09 & 72.05 \\
\hline & December & 118.70 & 133.75 & 126.23 & 63.11 \\
\hline \multirow{12}{*}{2010} & January & 134.40 & 167.74 & 151.07 & 75.53 \\
\hline & February & 100.90 & 159.07 & 129.98 & 64.99 \\
\hline & March & 103.60 & 129.43 & 116.51 & 58.26 \\
\hline & April & 124.90 & 133.87 & 129.38 & 64.69 \\
\hline & May & 116.35 & 113.17 & 114.76 & 57.38 \\
\hline & June & 135.58 & 130.50 & 133.04 & 66.52 \\
\hline & July & 198.00 & 147.00 & 172.50 & 86.25 \\
\hline & August & 194.00 & 170.00 & 182.00 & 91.00 \\
\hline & September & 179.33 & 154.48 & 166.90 & 83.45 \\
\hline & October & 170.13 & 153.93 & 162.03 & 81.01 \\
\hline & November & 147.42 & 138.54 & 142.98 & 71.49 \\
\hline & December & 151.25 & 129.63 & 140.44 & 70.22 \\
\hline \multirow{5}{*}{2011} & January & 154.92 & 116.61 & 135.76 & 67.88 \\
\hline & February & 183.54 & 127.03 & 155.29 & 77.64 \\
\hline & March & 181.29 & 141.17 & 161.23 & 80.61 \\
\hline & April & 98.04 & 157.75 & 127.89 & 63.95 \\
\hline & May & 91.25 & 87.32 & 89.28 & 44.64 \\
\hline \multicolumn{2}{|c|}{ An. Et 1st Year (mm) } & 1644.45 & 1655.94 & 1650.19 & 825.10 \\
\hline \multicolumn{2}{|c|}{ An. Et 2nd Year (mm) } & 1884.74 & 1653.94 & 1769.34 & 884.67 \\
\hline \multicolumn{2}{|c|}{ Annual ET (mm) } & 1764.60 & 1654.94 & 1709.77 & 854.88 \\
\hline
\end{tabular}

Table 4. Calculation of adjusted evaporation coefficient 2009-2011.

\begin{tabular}{|c|c|c|c|c|c|c|}
\hline $\begin{array}{c}\text { Type of } \\
\text { Land Cover }\end{array}$ & Characteristics of Dominant Crops & $\begin{array}{c}\text { Area } \\
\left(\mathrm{Km}^{2}\right)\end{array}$ & $\begin{array}{c}\text { Percentage } \\
(\%)\end{array}$ & Kc \& Ke & Kadj. & $\begin{array}{c}\text { Actual } \\
\text { Kadj. }\end{array}$ \\
\hline \multirow[t]{3}{*}{ Column (1) } & (2) & (3) & (4) & (5) & {$\left[\mathrm{Ks}^{*}(5)\right]$} & $(4) *(5)$ \\
\hline & Banana trees & 59.92 & 23.26 & 1.10 & 0.91 & 0.21 \\
\hline & Rain-fed herbaceous crops: coffee, maize ... & 63.80 & 24.77 & 0.89 & 0.74 & 0.18 \\
\hline \multirow{2}{*}{ Agriculture } & Rain-fed shrub crops: sorghum, beans, cassava, potato & 64.72 & 25.13 & 0.77 & 0.64 & 0.16 \\
\hline & Grasses and shrubs & 0.14 & 0.05 & 0.70 & 0.58 & 0.00 \\
\hline Forest & Forests and scattered fields & 14.59 & 5.66 & 0.70 & 0.58 & 0.03 \\
\hline Urban & Paved surfaces and roof tops & 11.57 & 4.49 & 0.30 & 0.25 & 0.01 \\
\hline Wetland & Rice and papyrus & 42.85 & 16.63 & 1.00 & 0.83 & 0.14 \\
\hline $\begin{array}{c}\text { Entire } \\
\text { Catchment }\end{array}$ & & 257.57 & 100.00 & & & 0.74 \\
\hline
\end{tabular}


To estimate the final crop factors to be used for the calculation of the Actual Evapotranspiration (1973-1974), the land cover was assessed for the entire catchment during 1973-1974 (Table 5).

The adjusted evaporation coefficient $\left(K_{a d j}\right)$ is therefore equal to 0.75 .

The Actual Evapotranspiration (AET) becomes:

$$
A E T=768.55 \mathrm{~mm} \times 0.75=576.41 \mathrm{~mm}
$$

\section{a. Discharge in 2009-2010}

To investigate surface water discharge in Migina catchment, five gauging stations were installed in 2009 Table 6.

Before the newly installed gauging stations in 2009, six old gauging stations were installed in 1993, but were destroyed during the Rwandan crisis of 1994. Therefore, Runoff coefficient was used to deduce the amount of discharge that flowed out of Migina catchment between 1973 and 1974. The rational method (Equation (2.6)) was used to know the runoff coefficient for the catchment.

\section{Table 5. Calculation of adjusted evaporation coefficient for 1973-1974.}

\begin{tabular}{|c|c|c|c|c|c|c|}
\hline $\begin{array}{c}\text { Type of } \\
\text { Land Cover }\end{array}$ & Characteristics of Dominant Crops & $\begin{array}{c}\text { Area } \\
\left(\mathbf{K m}^{2}\right)\end{array}$ & $\begin{array}{c}\text { Percentage } \\
\text { (\%) }\end{array}$ & Kc \& Ke & $\mathbf{K}_{\text {adj. }}$ & $\begin{array}{l}\text { Actual } \\
\mathbf{K}_{\text {adj. }}\end{array}$ \\
\hline Column (1) & (2) & (3) & (4) & (5) & {$\left[\mathrm{Ks}^{*}(5)\right]$} & $(4) *(5)$ \\
\hline \multirow{4}{*}{ Agriculture } & Banana trees & 63.52 & 24.66 & 1.10 & 0.91 & 0.23 \\
\hline & Rain-fed herbaceous crops: coffee, maize & 67.64 & 26.26 & 0.89 & 0.74 & 0.19 \\
\hline & Rain-fed shrub crops: sorghum, beans, cassava, potato & 68.60 & 26.64 & 0.77 & 0.64 & 0.17 \\
\hline & Grasses and shrubs & 0.14 & 0.06 & 0.70 & 0.58 & 0.00 \\
\hline Forest & Forests and scattered fields & 19.78 & 7.68 & 0.70 & 0.58 & 0.04 \\
\hline Urban & Paved surfaces and roof tops & 1.73 & 0.67 & 0.30 & 0.25 & 0.00 \\
\hline Wetland & Rice and papyrus & 36.16 & 14.04 & 1.00 & 0.83 & 0.12 \\
\hline $\begin{array}{c}\text { Entire } \\
\text { Catchment }\end{array}$ & & 257.57 & 100.00 & & & 0.75 \\
\hline
\end{tabular}

Table 6. Average discharge for 2009-2010.

\begin{tabular}{|c|c|c|}
\hline Year & Month & Discharge (Q) $\left[\mathrm{m}^{3} / \mathrm{s}\right]$ \\
\hline \multirow{5}{*}{2009} & August & 0.31 \\
\hline & September & 0.46 \\
\hline & October & 0.62 \\
\hline & November & 1.30 \\
\hline & December & 0.56 \\
\hline \multirow{7}{*}{2010} & January & 2.10 \\
\hline & February & 2.05 \\
\hline & March & 1.33 \\
\hline & April & 1.42 \\
\hline & May & 2.49 \\
\hline & June & 0.54 \\
\hline & July & 0.36 \\
\hline \multicolumn{2}{|c|}{ Avg. } & 1.13 \\
\hline
\end{tabular}


For urban areas, the runoff coefficient is $C_{1}=1$.

The $C_{2}$ (runoff coefficient) for the remaining land cover was therefore obtained as shown below;

$$
\begin{gathered}
1.13 \mathrm{~m}^{3} / \mathrm{s}=0.00278 \times 0.15 \mathrm{~mm} / \mathrm{hr} \times\left(1 \times 1156.5198 \mathrm{ha}+C_{2} \times 24600.65423 \mathrm{ha}\right) \\
C_{2}=\frac{(1.13-0.4823)}{10.26}=0.06
\end{gathered}
$$

The discharge

$$
Q_{p}=0.00278 \times 0.136 \mathrm{~mm} / \mathrm{hr} \times(1 \times 172.52 \mathrm{ha}+0.06 \times 25584.65 \mathrm{ha})=0.65 \mathrm{~m}^{3} / \mathrm{s}
$$

\section{Results and Discussions}

\subsection{Water Balance of Migina Catchment between 2009 and 2011}

The water balance (Equation (2.1)) is given by:

$$
\text { Inflows }- \text { Outflow }= \pm \text { Storage }
$$

Inflows in this study are related to Precipitation $(P)$.

Outflow relates to Evapotranspiration $(E)+$ Outlet discharge $(Q)$.

Stock $(S)$ is the quantity of water stored in the catchment.

Therefore, the inflow in Migina catchment or the annual rainfall for June 2009-May 2011 is $1325.34 \mathrm{~mm}$.

The outflow for Migina catchment is represented by evapotranspiration and outlet discharge where the annual reference evapotranspiration is $854.88 \mathrm{~mm}$ while the annual actual evapotranspiration for Migina catchment is equal to $597.80 \mathrm{~mm}$. Also, the outlet discharge (the average) is equal to $1.13 \mathrm{~m} / \mathrm{s}$.

In estimating the water balance of Migina catchment for June 2009-May 2011, the following equation was used $A(P-E)-Q=\Delta S$.

From the results obtained:

$$
\begin{gathered}
A=257.571740 \mathrm{~km}^{2}=257571740 \mathrm{~m}^{2} \\
P=1325.34 \mathrm{~mm}=1.32534 \mathrm{~m} \\
E=597.8 \mathrm{~mm}=0.5978 \mathrm{~m} \\
Q=1.13 \mathrm{~m}^{3} / \mathrm{s}=35635680 \mathrm{~m}^{3} / \text { year }
\end{gathered}
$$

The water balance of Migina catchment during June 2009 to May 2011 is calculated and found to be:

$$
[(1.32534-0.597) \times 257571740] \mathrm{m}^{3}-35635680 \mathrm{~m}^{3}=151964121 \mathrm{~m}^{3}
$$

And can be simplified as:

$$
341370129.9 \mathrm{~m}^{3}-153770328.8 \mathrm{~m}^{3}-35635680=151964121 \mathrm{~m}^{3}
$$

The change in stock within Migina catchment during June 2009 to May 2011 is estimated to be 152 millions of $\mathrm{m}^{3}$.

\subsection{Water Balance of Migina Catchment between 1973 and 1974}

The inflow in Migina catchment (annual rainfall for 1973-1974) is $1191.5 \mathrm{~mm}$. The outflow such as the annual reference evapotranspiration is equal to $768.55 \mathrm{~mm}$. Therefore, the annual actual evapotranspiration for Migina catchment is equal to $576.41 \mathrm{~mm}$. Meanwhile, the average discharge for 1973-1974 stands at $0.65 \mathrm{~m}^{3} / \mathrm{s}$.

The water balance of Migina catchment for 1973-1974 is obtained as follows;

From the results obtained:

$$
\begin{gathered}
A=257.571740 \mathrm{~km}^{2}=257571740 \mathrm{~m}^{2} \\
P=1191.5 \mathrm{~mm}=1.1915 \mathrm{~m} \\
E=576.41=0.576 \mathrm{~m}
\end{gathered}
$$




$$
Q=0.65 \mathrm{~m}^{3} / \mathrm{s}=20498400 \mathrm{~m}^{3} / \text { year }
$$

The water balance of Migina catchment during 1973-1974 is calculated and found to be:

$$
[(1.1915-0.576) \times 257571740] \mathrm{m}^{3}-20498400 \mathrm{~m}^{3}=138037006 \mathrm{~m}^{3}
$$

And can be simplified as:

$$
306896728.2 m^{3}-148361322.2 m^{3}-20498400 m^{3}=138037006 m^{3}
$$

The change in stock within Migina catchment during 1973-1973 is estimated to be 138 million of $\mathrm{m}^{3}$.

\subsection{Impact of Urbanization on the Water Balance of Migina Catchment}

\section{a) During 2009 and 2011}

Evapotranspiration represents $45 \%$ of the total inflow, while runoff represents $10.5 \%$ of the total inflow and change in storage represents $44.5 \%$ of the total inflow.

\section{b) During 1973-1974}

Evapotranspiration in $1973 / 1974$ is $48 \%$ of the total inflow, runoff is $7 \%$ of the total inflow and change in storage is $45 \%$ of the total inflow. These findings tally and are in close range as that given in [22]. These studies revealed that, during the last 30 years the runoff has increased by 3.5\%. This may be attributed to the infiltration of water into the soil [23] [24].

This may also lead to increase pollution due to surface water run-off which may also spread water borne diseases as a result of little or no water self-purification. This increase in runoff also reduces water storage hence leads to water scarcity within the surrounding area [25]-[27].

A decrease of $3 \%$ in evapotranspiration maybe due to the conversion of green spaces for urbanization purposes especially housing. This reduces surface albe do hence a drop in the contribution of evapotranspiration to rainfall. A progressive reduction in rainfall is gradually created with consequences for agriculture due to recurrent droughts [24] [26]. The change in storage has slightly decreased by $0.5 \%$ because increase runoff causes out- flow of catchment water that could have been stored as groundwater [26] [27].

These changes in the hydrological cycle could be attributed to the new residential plots of Butare town whose population increased from a mere 8400 in 1970 to over 100,000 inhabitants in 2009. This growth in population has been detrimental to the natural landscape cover hence fluctuations in the hydrological cycle.

\section{Conclusions}

The water balance of Migina catchment was estimated over a 30-year interval with more rainfall experienced during 1973/1974 in Migina catchment than in 2009-2011. These observations were also true for surface water runoff which was considerably lower in 1973/1974 and higher in 2009-2011. These changes are all due to an increase in demand for basic and social amenities as a result of an increase in population of Butare town.

The consequences of urbanization on the hydrological cycle could be curtailed by structural adjustment programmes including urban greening and provision of detention of runoff water in urban drainage systems.

\section{References}

[1] Munyaneza, O., Mukubwa, A., Maskey, S., Wenninger, J. and Uhlenbrook, S. (2013) Assessment of Surface Water Resources Availability Using Catchment Modeling and the Results of Tracer Studies in the Meso-Scale Migina Catchment, Rwanda. Hydrology and Earth System Sciences Discussions, 10, 15375-15408. http://dx.doi.org/10.5194/hessd-10-15375-2013

[2] Adrian, B. and Pede, Z. (2012) Design in Nature: How the Constructal Law Governs Evolution in Biology, Physics, Technology, and Social Organization. Random House, New York.

[3] UNCE (2015a) University of Nevada Cooperative Extension. Effects of Urbanization on the Water Cycle. http://www.unce.unr.edu/publications/files/nr/2004/FS0443.pdf

[4] Mukete, B. and Sun, Y. (2014) Assessing the Effectiveness of Urban Nature Reserves on Biodiversity Conservation. Applied Ecology and Environmental Sciences, 2, 130-134. http://dx.doi.org/10.12691/aees-2-6-1

[5] Nahayo, D., Wali, U. and Anyemedu, F. (2010) Irrigation Practices and Water Conservation Opportunities in Migina Marshlands. International Journal of Ecology and Development, 16, 100-112. 
[6] Mugabe, T., Chitata, T., Kashaigili, J., Chagonda, I. and Nyagumbo, I. (2011) Modelling the Effect of Rainfall Variability, Land Use Change and Increased Reservoir Abstraction on Surface Water Resources in Semi-Arid Southern Zimbabwe. Physics and Chemistry of the Earth, Parts A/B/C, 36, 1025-1032. http://dx.doi.org/10.1016/j.pce.2011.07.058

[7] Munyaneza, O., Wali, U., Ufiteyezu, F. and Uhlenbrook, S. (2011) A Simple Method to Predict River Flows in an Agricultural Catchment in Rwanda. Nile Water Science and Engineering Journal, 4, 24-36.

[8] Ufiteyezu, F. (2010) Prediction of Migina River Discharge in Contribution to Hydrometeorology in Rwanda. National University of Rwanda, Butare, Rwanda.

[9] Hategekimana, D. (2007) Water Balance of Lake Muhazi. MSc Thesis, National University of Rwanda, Butare, Rwanda.

[10] UNCE (2015b) University of Nevada Cooperative Extension. Urbanization and the Water Cycle. http://www.unce.unr.edu/publications/files/ho/2005/av0512.pdf

[11] Mukete, B. and Monono, S. (2014) Assessing the Impact of Consumer Behaviour on Food Security in South West Cameroon. Journal of Food Security, 2, 87-91.

[12] Central Intelligence Agency (CIA) (2015) The World Factbook. https://www.cia.gov/library/publications/the-world-factbook/fields/2212.html

[13] United Nations Organization (UN) (2015) UN Data: A World of Information. http://data.un.org/CountryProfile.aspx?crName=RWANDA

[14] REMA (2009) Economic Impact of Climate Change in Rwanda. REMA, Kigali, Rwanda. Savenije, H. and De Laat, P. (1992) Textbook of Hydrology. Delft, The Netherlands.

[15] Munyaneza, O. (2008) Space-Time Patterns of Hydrological Processes and Water Resources in Rwanda, with Special Focus on the Meso-Scale Migina Catchment. PhD Research Proposal, UNESCO-IHE Institute for Water Education, Delft, The Netherlands.

[16] Ying, H., Gerdo, A., Charle, W., Julia, C., Adriaan, G., Matthew, S. and Alexander, R. (2011) The Infrastructure Research Initiative at SWA. Germany.

[17] Iraguha, G. (2006) Etude de la dynamique des paysages par télédétection: Cas de la ville de Butare. Mémoire, National University of Rwanda, Butare.

[18] Van den Berg, W. and Bolt, H. (2010) Catchment Analysis in the Migina Marshlands, Southern Rwanda. MSc Thesis, Vrije University Amsterdam, Amsterdam.

[19] Musoni, J., Wali, U. and Munyaneza, O. (2009) Runoff Coefficient Classification on Nyabugogo Catchment. 10th International Waternet/Warfsa/GWP-SA Symposium, Entebbe, 28-30 October 2009.

[20] Carlos, E. and Tucci, M. (2007) Urban Flood Management. Hydraulic Research Institute, Federal University of Rio Grande, Rio Grande.

[21] Chibulu, B. (2007) Effect of Rainfall Variability on Crop Yield under Semi-Arid Conditions at Sub-Catchment Level. MSc Thesis, University of Zimbabwe, Harare.

[22] Mukete, B. (2014) Overpopulation and Biodiversity Conservation in Sub-Saharan Africa. In Discussions on Forest Conservation Issues of Sub-Saharan Africa Series 1 Volume 2. https://www.academia.edu/7759415/Overpopulation and Biodiversity Conservation in Sub-Saharan Africa

[23] Nicholson, S. (2001) Climatic and Environmental Change in Africa during the Last Two Centuries. Climate Research, 17, 123-144. http://dx.doi.org/10.3354/cr017123

[24] Mearns, R. and Norton, A. (2010) Social Dimensions of Climate Change: Equity and Vulnerability in a Warming World. New Frontiers of Social Policy, World Bank Publications No. 52097.

[25] Fatemeh, A. (2011) A Methodology for Risk-Based Optimization of Urban Drainage System. MSc Thesis, Vrije University Amsterdam, Amsterdam.

[26] Tsheko, R. (2003) Rainfall Reliability, Drought and Flood Vulnerability in Botswana. Water SA, 29, 389-392.

[27] Fischer, B. and Savenije, H. (2009) A Spatial and Temporal Rainfall Analysis of the Pangani Basin and Makanya Catchment, Tanzania. Geographycal Research Abstracts, 11, 79-86. 
Submit or recommend next manuscript to OALib Journal and we will provide best service for you:

- Publication frequency: Monthly

- 9 subject areas of science, technology and medicine

- Fair and rigorous peer-review system

- Fast publication process

- Article promotion in various social networking sites (LinkedIn, Facebook, Twitter, etc.)

- Maximum dissemination of your research work

Submit Your Paper Online: Click Here to Submit

Contact Us: service@oalib.com 